\title{
Efektivitas Pupuk Organik Cair Limbah Rumah Tangga dalam Meningkatkan Pertumbuhan dan Produksi Tanaman Tomat (Lycopersicum esculentum Mill.)
}

\author{
Lidia Sunarti Pantang1, Yusnaeni', Andam S. Ardan', Sudirman ${ }^{2}$ \\ ${ }^{1}$ Program Studi Pendidikan Biologi, Fakultas Keguruan dan Ilmu Pendidikan, Universitas Nusa Cendana \\ ${ }^{2}$ Program Studi Pendidikan Kimia, Fakultas Keguruan dan Ilmu Pendidikan, Universitas Nusa Cendana \\ email: yusnaeni_75@yahoo.co.id
}

\begin{tabular}{l} 
Article History \\
\hline Received: \\
17/02/2021 \\
Revised: \\
21/03/2021 \\
Accepted: \\
$24 / 04 / 2021$ \\
Kata kunci: \\
Pupuk organik \\
cair \\
Limbah rumah \\
tangga \\
Pertumbuhan \\
Produksi \\
Key word: \\
Liquid organic \\
fertilizer \\
Household \\
waste \\
Growth \\
Production
\end{tabular}

\begin{abstract}
ABSTRAK
Penelitian bertujuan untuk mengetahui pengaruh pupuk organik cair limbah rumah tangga terhadap pertumbuhan dan produksi tanaman tomat serta mengetahui volume efektif dari pupuk organik cair yang memberikan hasil terbaik terhadap pertumbuhan dan produksi tanaman tomat. Penelitian adalah penelitian eksperimen menggunakan Rancangan Acak Lengkap dengan 4 perlakuan volume pupuk per polybag yaitu 0 (kontrol), 50, 100, dan $150 \mathrm{~mL}$. Tiap perlakuan diulang 5 kali. Variabel yang diukur adalah tinggi tanaman, jumlah buah, dan berat basah buah. Data hasil pengamatan dianalisis dengan menggunakan analisis varians dan diuji lanjut Tukey dengan menggunakan program SPSS Ver.18. Hasil analisis varians diperoleh bahwa perlakuan pupuk organik cair limbah rumah tangga berpengaruh sangat nyata terhadap variabel tinggi tanaman, jumlah buah, dan berat basah buah, dimana masing-masing variabel menunjukkan nilai signifikansi lebih kecil dari 0,01. Hasil uji lanjut diperoleh bahwa perlakuan yang paling baik adalah perlakuan dengan volume $150 \mathrm{~mL} /$ polybag untuk variabel tinggi tanaman, jumlah buah, dan berat basah buah.
\end{abstract}

ABSTRACT
This study aims to determine the effect of household waste liquid organic fertilizer on the growth
and production of tomato plants and to determine the effective volume of liquid organic fertilizer
which gives the best results on the growth and production of tomato plants. The study was an
experimental study using a completely randomized design with 4 treatments of fertilizer volume
per polybag, namely 0 (control), 50,100 , and $150 \mathrm{~mL}$. Each treatment was repeated 5 times. The
variables measured were plant height, number of fruits, and fruit wet weight. Observation data
were analyzed using analysis of variance and Tukey continued testing using the SPSS Ver.18
program. The results of the analysis of variance showed that the treatment of liquid organic
fertilizer household waste had a very significant effect on the variables of plant height, number of
fruit, and fruit wet weight, where each variable showed a significance value less than 0.01 . Further
test results obtained that the best treatment is treatment with a volume of $150 \mathrm{~mL} /$ polybag for
variable plant height, number of fruit, and fruit wet weight.

Copyright ${ }^{\circ} 2021$ LPPM Universitas Indraprasta PGRI. All Right Reserved

\section{PENDAHULUAN}

Kebutuhan manusia, khususnya kebutuhan akan pangan meningkat seiring berjalannya waktu. Peningkatan kebutuhan pangan menyebabkan adanya perilaku konsumtif yang dapat menjadi andil meningkatnya produksi limbah termasuk limbah rumah tangga.

Limbah limbah rumah tangga merupakan sisasisa dari pemakaian dan proses atau kegiatan rumah tangga yang tidak terpakai lagi. Jenis limbah rumah tangga sangat beragam, tetapi secara umum sekitar $75 \%$ terdiri dari sampah organik dan sisanya adalah sampah anorganik (Sudradjat, 2007). Produk hasil aktivitas rumah tangga merupakan penghasil limbah terbesar yang menyebar dan dapat mencemari lingkungan. Peningkatan produksi limbah menjadi salah satu permasalahan bagi lingkungan hidup yang perlu ditanggulangi. Salah satu upaya penanggulangan yang dapat dilakukan yakni dengan mengolah dan memanfaatkan limbah tersebut menjadi produk 
bernilai ekonomi tinggi salah satunya adalah mengolah limbah menjadi pupuk organik.

Pupuk organik merupakan pupuk yang berasal dari bahan-bahan organik seperti sisa-sisa tanaman, kotoran hewan, dan serbuk kayu. Pupuk organik mengandung lebih banyak bahan organik dibandingkan pupuk anorganik. Kelebihan dari pemanfaatan limbah organik adalah menghasilkan pupuk yang ramah lingkungan.

Pupuk organik dapat berwujud padat dan cair. Pupuk organik cair lebih efektif digunakan dibandingkan pupuk organik padat. Pupuk organik cair (POC) merupakan jenis pupuk organik yang berwujud cair dan mudah larut dalam tanah. POC memiliki beberapa keunggulan yakni pengolahan mudah dan tidak membutuhkan waktu yang lama, mudah diserap oleh tanaman, dapat memperbaiki struktur partikel tanah, dan mudah pengaplikasiannya

Beberapa limbah rumah tangga dapat dijadikan bahan dasar pembuatan pupuk organik cair. Bahan tersebut dapat berupa kulit pisang, cangkang telur dan ampas teh. Kulit pisang pisang mengandung unsur P, K, Ca, Mg, Na, Zn (Sriningsih, 2013). Kandungan hara tersebut dapat berfungsi untuk memacu pertumbuhan dan perkembangan tanaman yang berdampak pada jumlah produksi yang maksimal. Hasil penelitian pemanfaatan limbah kulit pisang sebagai pupuk organik telah dilakukan oleh Manis et al. (2017) melaporkan bahwa POC dari kulit pisang memiliki kadar nitrogen total sebesar $0.032 \%$. Pengaplikasian pada dosis $40 \mathrm{ml}$ berpengaruh nyata terhadap tinggi tanaman, jumlah daun, dan berat basah tanaman kangkung darat. Penelitian lain yang dilakukan oleh Masayu (2015) juga mengungkap bahwa pemberian POC dari kulit pisang dengan beberapa konsentrasi meningkatkan pertumbuhan tanaman kedelai pada semua parameter yang diukur.

Selain kulit pisang, cangkang telur juga dapat dimanfaatkan sebagai sumber nutrisi bagi tanaman, dimana berdasarkan laporan Aditya (2014) menjelaskan bahwa cangkang telur mengandung kalium (K) sebesar 0.121\%; kalsium (Ca) sebesar 8.977\%; fosfor (F) sebesar $0.394 \%$ dan magnesium $(\mathrm{Mg})$ sebesar $10.541 \%$. Kandungan Ca yang cukup tinggi merupakan alasan mengapa cangkang telur dapat dimanfaatkan sebagai bahan pembuatan POC. Hasil penelitian Mashfufah (2014) mengungkap bahwa pupuk organik dari cangkang telur memberikan pengaruh nyata terhadap pertumbuhan tanaman seledri pada konsentrasi 7.5\%. Febrianti (2017), juga melaporkan bahwa pemberian serbuk cangkang telur pada konsentrasi 300 ppm dalam media tumbuh memberikan pengaruh yang sangat baik terhadap pertumbuhan tinggi tanamandan jumlah daun bayam.

Limbah rumah tangga yang lain yang juga berpotensi untuk dijadikan bahan pembuatan POC adalah ampas kopi. Ampas kopi mengandung beberapa unsur hara penting bagi tanaman yakni N, $\mathrm{P}, \mathrm{K}, \mathrm{Na}, \mathrm{Mg}$, dan $\mathrm{Ca}$. Menurut Caetano dkk. (2012), kandungan terbanyak dalam ampas kopi adalah karbon dengan total karbon mencapai 47.8\%-58.9\%. Kasongo et al. (2011) juga menambahkan bahwa komposisi mineral yang terkandung dalam ampas kopi yakni $\mathrm{Ca}(0.37 \%)$, Mg sebesar (0.14\%), K (2.49\%), Na (0.04\%) dan F (0.18\%). Putri et al. (2017) melaporkan bahwa limbah kopi cair $10 \mathrm{~g} / 100 \mathrm{~mL}$ memberikan pengaruh paling baik terhadap tinggi tanaman, jumlah daun, berat basah, panjang akar, berat basah, dan berat kering tanaman selada.

Berdasarkan hasil-hasil penelitian yang telah diungkap sebelumnya, dalam penelitian ini, dicoba mengkombinasikan ketiga bahan limbah tersebut kemudian divariasikan volume penyiramannya untuk melihat pada volume berapa yang paling baik dalam meningkatkan pertumbuhan dan produksi tanaman.

Tanaman yang dapat dijadikan objek pengujian penggunaan POC limbah rumah tangga adalah tanaman tomat dengan pertimbangan banyak dimanfaatkan oleh masyarakat karena nilai gizinya berupa vitamin dan mineral, tomat juga menjadi salah satu komoditas pertanian karena dapat menunjang perekonomian. Dengan banyaknya manfaat tanaman tomat, maka dipandang perlu untuk meningkatkan kualitas pertumbuhannya melalui pemupukan dari bahan organik.

\section{METODE PENELITIAN}

\section{a. Lokasi Penelitian}

Penelitian dilaksanakan di Kebun percobaan Pendidikan Biologi Universitas Nusa Cendana.

\section{b. Alat dan Bahan}

Alat yang digunakan adalah pisau, blender, gelas ukur, polybag, ember plastik, wadah beserta tutupan, alat ukur, alat tulis, kamera, dan kertas label, sedangkan bahan yang digunakan adalah limbah kulit pisang, cangkang telur, ampas kopi, bibit tanaman tomat, air, gula pasir, tanah, dan EM4.

\section{c. Rancangan Percobaan}

Penelitian ini merupakan penelitian eksperimen menggunakan Rancangan Acak Lengkap dengan 4 
perlakuan dan 5 ulangan. Total unit pengamatan ada 20 unit. Adapun perlakuannya adalah: kontrol (tanpa pemberian POC), POC $50 \mathrm{~mL} /$ polybag, POC $100 \mathrm{~mL} /$ polybag, dan POC $150 \mathrm{~mL} /$ polybag.

\section{d. Prosedur Penelitian}

1. Pembuatan POC dan Penyiapan Media Tanam Limbah kulit pisang, cangkang telur dan ampas kopi dikumpulkan dan dibersihkan. Sebanyak $1 \mathrm{~kg}$ kulit pisang, cangkang telur $1 \mathrm{~kg}$ dan ampas kopi $500 \mathrm{~g}$ diblender hingga halus (agar memudahkan proses penghalusan saat diblender, ditambahkan 1 L air). Hasil blenderan yang sudah halus diambil sebanyak $1 \mathrm{~kg}$ dicampurkan dengan $1 / 4 \mathrm{~kg}$ gula pasir dan ditambahkan $15 \mathrm{~mL}$ EM4, kemudian ditutup rapat dan dibiarkan selama 4 hari untuk proses fermentasi.

Penyiapan media tanam dilakukan dengan mengambil tanah yang sudah dibersihkan dari kotoran dan bebatuan kemudian disterilkan. Selanjutnya sebanyak $3 \mathrm{~kg}$ tanah tersebut diisi ke dalam polybag.

\section{Tahap Persemaian Benih}

Biji tomat yang telah direndam dalam air hangat selama 5 menit disemaikan dalam polybag berukuran $17.5 \times 40 \mathrm{~cm}$. Media semai berupa tanah yang dicampur dengan pupuk kandang dengan perbandingan 2:1. Setelah disemai selama 14 hari, semaian dipindahkan dalam polybag yang telah berisi media tanam.

\section{Aplikasi POC pada Tanaman}

Pupuk hasil fermentasi disaring untuk memisahkan ampas dengan cairan. POC yang dihasilkan diberikan pada tanaman tomat pada usia 14 hari setelah tanam (HST), sesuai dengan perlakuan Aplikasi POC dilanjutkan setiap 2 kali seminggu. Pemupukan dilakukan selama 6 minggu.

\section{Tahap Perawatan dan Pengamatan Variabel}

Penyiraman dilakukan 2 kali sehari yaitu pagi dan sore kecuali saat hujan. Untuk menghindari serangan hama, area sekitar tanaman dibersihkan agar tidak ditumbuhi gulma atau tumbuhan liar lainnya. Variabel yang diukur yaitu pertambahan tinggi tanaman tomat, jumlah buah, dan berat basah buah.

\section{e. Teknik Analisis Data}

Data hasil pengukuran (pertambahan tinggi tanaman tomat, jumlah buah, dan berat basah buah) dianalisis dengan menggunakan analisis varians (ANAVA) satu arah dan uji lanjut menggunakan uji Tukey dengan menggunakan program SPSS Windows-18 (Sugiyono, 2012).

\section{HASIL DAN PEMBAHASAN}

Hasil analisis deskriptif pada perlakuan POC limbah organik rumah tangga secara deskriptif memberi efek yang berbeda-beda sesuai dengan perlakuan masing-masing terhadap variabel tinggi tanaman, jumlah buah, dan berat basah buah. Ratarata tinggi tanaman pada masing-masing perlakuan volume POC limbah rumah tangga dapat dilihat pada Gambar 1.

Gambar 1, memperlihatkan bahwa perlakuan POC dengan volume $150 \mathrm{~mL} /$ polybag dapat meningkatkan tinggi tanaman, jumlah buah dan berat basah buah yang paling besar dibandingkan dengan perlakuan volume lainnya. Selanjutnya, rekapitulasi hasil analisis varians pada variabel tinggi tanaman, jumlah buah, dan berat basah buah selengkapnya disajikan pada Tabel 1. Tabel 1, memperlihatkan bahwa pemberian perlakuan pupuk POC limbah rumah tangga berpengaruh terhadap ketiga variabel yang diukur yakni pertambahan tinggi, jumlah buah, dan berat basah, dimana nilai sig masing-masing variabel lebih kecil dari 0.05. Karena menunjukkan pengaruh perlakuan, maka dilanjutkan dengan uji lanjut Tukey. Hasil uji Tukey dapat dilihat pada Tabel 2.

Tabel 2 menunjukkan bahwa ketiga variabel yang diukur yakni pertambahan tinggi, jumlah buah dan berat basah buah menunjukkan perbedaan antar perlakuan. Untuk Variabel tinggi tanaman terlihat bahwa kontrol dan perlakuan POC $50 \mathrm{~mL}$ tidak berbeda, demikian pula untuk perlakuan 50 $\mathrm{mL}$ tidak berbeda dengan POC $100 \mathrm{~mL}$. Perlakuan yang paling baik dan berbeda dengan lainnya adalah perlakuan POC $150 \mathrm{~mL} /$ polybag. Sementara untuk variabel jumlah buah dan berat basah buah terlihat bahwa perlakuan POC $100 \mathrm{~mL} /$ polybag tidak berbeda dengan perlakuan $150 \mathrm{~mL}$. Namun dari semua perlakuan yang diberikan, perlakuan POC $150 \mathrm{~mL} /$ polybag yang paling baik.

Tabel 1. Rekapitulasi hasil anava variabel pertambahan tinggi, jumlah buah, dan berat basah buah tanaman tomat

\begin{tabular}{lcc}
\hline \multicolumn{1}{c}{ Variabel Penelitian } & F & Sig. \\
\hline Pertambahan Tinggi & 12.476 & 0.000 \\
\hline Jumlah Buah & 7.037 & 0.003 \\
\hline Berat Basah Buah & 6.110 & 0.006 \\
\hline Ke
\end{tabular}

Ket: Perlakuan sangat berpengaruh jika nilai sig. $<0.01$ 
a

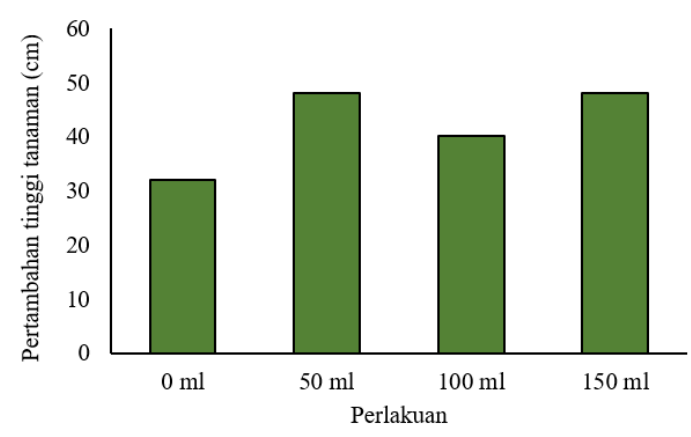

b

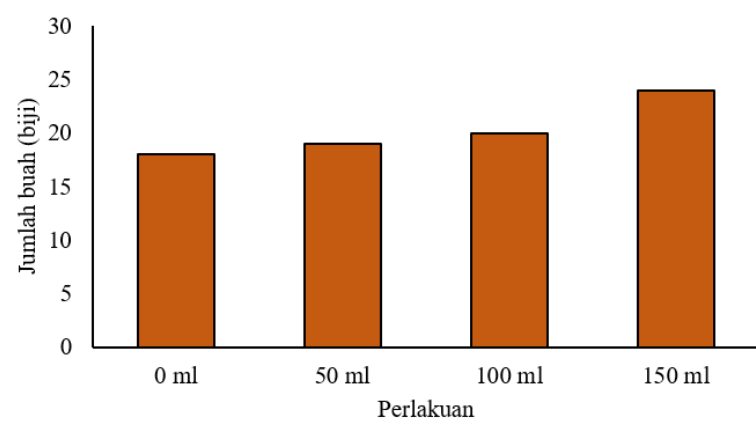

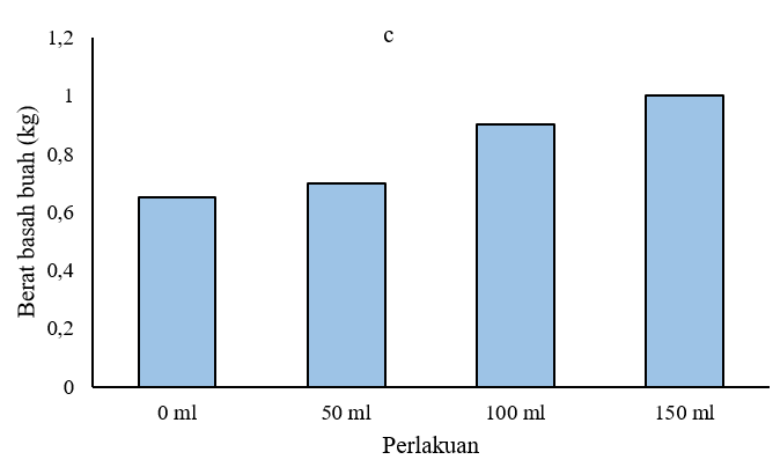

Gambar 1. Grafik rata-rata: (a) pertambahan tinggi tanaman, (b) jumlah buah, dan (c) berat basah buah pada masingmasing perlakuan $\mathrm{POC}$

Tabel 2. Rekapitulasi hasil uji lanjut tukey pada masing-masing variabel dan perlakuan

\begin{tabular}{lccc}
\hline \multicolumn{1}{c}{ Variabel } & Perlakuan & Rata-rata & Notasi \\
\hline Pertambahan & $0 \mathrm{~mL}$ & 29.84 & $\mathrm{a}$ \\
Tinggi & $50 \mathrm{~mL}$ & 35.72 & $\mathrm{ab}$ \\
Tanaman $(\mathrm{cm})$ & $100 \mathrm{~mL}$ & 38.76 & $\mathrm{bc}$ \\
& $150 \mathrm{~mL}$ & 44.86 & $\mathrm{c}$ \\
\hline Jumlah Buah & $0 \mathrm{~mL}$ & 17 & $\mathrm{a}$ \\
(biji) & $50 \mathrm{~mL}$ & 18 & $\mathrm{a}$ \\
& $100 \mathrm{~mL}$ & 20 & $\mathrm{ab}$ \\
& $150 \mathrm{~mL}$ & 23 & $\mathrm{~b}$ \\
\hline Berat Basah & $0 \mathrm{~mL}$ & 0.628 & $\mathrm{a}$ \\
Buah $(\mathrm{Kg})$ & $50 \mathrm{~mL}$ & 0.688 & $\mathrm{a}$ \\
& $100 \mathrm{~mL}$ & 0.844 & $\mathrm{ab}$ \\
& $150 \mathrm{~mL}$ & 0.960 & $\mathrm{~b}$ \\
\hline
\end{tabular}

Keterangan: Angka yang diikuti dengan huruf yang sama tidak menunjukkan perbedaan

Berdasarkan hasil analisis deskriptif dan hasil analisis varians diperoleh bahwa pemberian POC limbah rumah tangga memberikan pengaruh terhadap pertumbuhan dan produksi tanaman tomat, dan dari hasil uji lanjut Tukey diperoleh bahwa perlakuan yang terbaik adalah perlakuan dengan volume $150 \mathrm{~mL} /$ polibag. Hasil ini ini mengindikasikan bahwa pemberian POC limbah rumah tangga mampu menyuplai unsur hara yang beragam dalam jumlah yang optimal untuk mendukung pertumbuhan dan produksi tanaman tomat. Pemberian POC dengan volume berbeda memberikan pengaruh yang berbeda pula terhadap pertambahan tinggi tanaman tomat, karena jumlah unsur hara yang terkandung dalam pupuk juga berbeda. Beberapa hasil penelitian sebelumnya yang relevan dengan bahan POC dalam penelitian ini antara lain Diatri et al. (2018) yang menjelaskan bahwa pemberian pupuk organik kulit pisang berpengaruh pada pertumbuhan bayam merah. Juliani (2017) melaporkan bahwa pemberian kompos ampas kopi memberikan pengaruh nyata terhadap parameter tinggi batang dan jumlah daun tanaman cabai merah keriting.

Hara utama yang diduga memberi peran dalam pertumbuhan dan produksi tanaman tomat adalah unsur hara nitrogen $(\mathrm{N})$ dalam POC. Unsur nitrogen tersebut berasal dari perombakan protein dalam kulit pisang dan ampas kopi oleh aktifitas enzim protease yang disekresi oleh bakteri asam laktat dan Actinomycetes yang terdapat dalam larutan EM4 (Nur dkk., 2016). Hal ini sesuai dengan yang dijelaskan oleh Pappang (2018) bahwa bakteri asam laktat dan Actinomycetes mampu menghasilkan enzim protease yang dapat 
memecah protein menjadi polimer penyusunnya. Hasil penelitian Rahmadina \& Tambunan (2017) menunjukkan bahwa limbah cangkang telur ayam dapat diolah menjadi pupuk organik dengan kadar hara yang tinggi untuk pupuk organik dari cangkang telur yaitu $\mathrm{N} 0.18 \%$ dengan kadar sedang. Munawar (2011) menambahkan bahwa unsur $\mathrm{N}$ merupakan salah satu unsur hara makro yang umumnya diperlukan bagi pertumbuhan vegetatif tanaman seperti akar, batang, dan daun. Patti dkk. (2013) juga menambahkan bahwa nitrogen sangat penting dalam pembentukan klorofil, protoplasma, protein, dan asam nukleat dan juga merupakan komponen penyusun auksin, dimana auksin berperan dalam pertumbuhan jaringan meristem apikal yang menyebabkan tanaman bertambah tinggi.

Menurut Cruz et al. (2012), limbah kopi mengandung $1.2 \%$ Nitrogen, $0.02 \%$ Fosfor, dan $0.35 \%$ Kalium. Adanya kandungan hara ini berkombinasi dengan kandungan hara pada kulit pisang cangkang telur turut berkonstribusi meningkatkan pertubuhan dan produksi tanaman.

Selain unsur nitrogen, kandungan hara $\mathrm{Ca}$ dalam POC yang berasal dari kulit pisang dan cangkang telur juga mempengaruhi pertumbuhan batang tanaman tomat. Nurjayanti dkk. (2012), mengungkap bahwa cangkang telur mengandung garam-garam organik (sekitar 95.1\%) dan bahan organik (terutama protein sekitar 3.3\%). Unsur Ca dalam POC ini berasal dari pelarutan kalsium karbonat oleh asam laktat yang dihasilkan oleh bakteri asam laktat dalam larutan EM4. Peran Ca diungkap oleh Munawar (2011); Syam dkk. (2014); Salisbury \& Ross (1995) bahwa Ca sangat menguntungkan bagi tanaman karena $\mathrm{Ca}$ dapat mengaktifkan pembentukan bulu-bulu akar dan biji serta menguatkan batang, sebagai komponen dinding sel, membantu pertumbuhan dan pembelahan sel, kofaktor enzim, serta memainkan peran dalam struktur dan permeabilitas membran sel.

POC limbah organik rumah tangga dalam penelitian ini memberi pengaruh terhadap produksi buah (jumlah dan berat basah) diduga karena kandungan beberapa unsur hara dalam POC khususnya fosfor yang berasal dari limbah kulit pisang, dimana fosfat sangat diperlukan dalam perkembangan generatif tumbuhan. Hal ini sejalan dengan Sutejo (2002) yang mengungkap bahwa unsur hara fosfor membantu mempercepat pertumbuhan tanaman dewasa, dan merangsang pertumbuhan bagian-bagian generatif bertumbuh dan berkembang sehingga menghasilkan jumlah buah yang banyak pula.
Berdasarkan hasil uji lanjut diperoleh bahwa POC dengan volume penyiraman $150 \mathrm{~mL} /$ polibag menghasilkan jumlah buah terbanyak. Hal tersebut diduga karena dengan dosis POC tersebut mampu menyuplai unsur fosfor yang mengoptimalkan perkembangan organ generatif khususnya buah sehingga dapat menghasilkan buah yang banyak.

Selain berpengaruh pada jumlah buah, juga berpengaruh berat basah buah tomat. Adanya bahan-bahan organik seperti unsur hara kalium (K) dari limbah ampas kopi, dan magnesium $(\mathrm{Mg})$ dari limbah cangkang telur dalam POC yang mendukung kualitas produksi buah. Kalium yang terkandung dalam limbah kopi berperan juga dalam proses pembentukan daun, dimana ketersediannya dapat melancarkan proses pembentukan daun (Sitompul, 2015). Kalium digunakan tanaman untuk aktivasi enzim dan juga berperan dalam fotosintesis. Sutejo (2002) juga menambahkan bahwa unsur kalium dalam tanaman berfungsi meningkatkan resistensi tanaman terhadap penyakit, meningkatkan kualitas buah dan biji serta membantu pembentukan protein dan karbohidrat. Lebih lanjut Munawar (2011) menerangkan bahwa keberadaan unsur magnesium dalam tanaman sangat esensial untuk proses sintesis makanan. Sintesis makanan yang berjalan secara sempurna mampu menyuplai makanan secara berkelanjutan bagi semua organ pada tanaman, sehingga mampu meningkatkan kualitas buah yang berdampak pada besarnya bobot atau berat basah buah. Unsur nitrogen dalam POC juga membantu pembentukan senyawa penting dalam proses fotosintesis dan pembelahan sel, sehingga tanaman dapat menghasilkan kualitas buah yang baik.

\section{KESIMPULAN}

Berdasarkan hasil penelitian yang telah dilakukan, maka dapat disimpulkan bahwa:

1. Pupuk Organik Cair (POC) limbah rumah tangga berpengaruh nyata terhadap pertumbuhan dan produksi tanaman tomat (Lycopersicum esculentum Mill.) dalam hal ini pada tinggi tanaman, jumlah buah, dan berat basah buah.

2. Volume efektif POC limbah rumah tangga yang memberikan hasil terbaik terhadap pertumbuhan dan produksi tanaman tomat adalah volume $150 \mathrm{~mL} /$ tanaman.

\section{DAFTAR PUSTAKA}

Aditya, A. R. (2014). Peranan Ekstrak Kulit Telur, Daun Gamal dan Bonggol Pisang sebagai

Pantang et al. Efektivitas Pupuk Organik Cair EduBiologia Volume 1 Number 2 Juli 2021 
Pupuk Organik terhadap Pertumbuhan Tanaman Cabai dan Populasi Aphis craccivora pada Fase Vegetatif. Skripsi. Universitas Hasannudin.

Caetano, N. S., Silva, V. F. M., \& Mata T. M. (2012). Valorization of coffee grounds for biodiesel production. Chemical Engineering Transactions, 26(1), 267-272.

Cruz, R., Baptista, P., \& Cunha, S. (2012). Carotenoid sof lettuce (Lactuca sativa L.) grown on soil enriched with spent coffee grounds. Molecules, 17(1), 1535-1547.

Diatri, E. A., Marlina, L., \& Zuhri, R. (2018). Pengaruh pemberian pupuk organik cair dari limbah kulit buah pisang lilin (Musa paradisiaca L.) terhadap pertumbuhan tanaman bayam merah (Amaranthus tricolor L. var Blitum rubrum). Biocolony, 1(2), 16 -24

Febrianti, A. (2017). Pemanfaatan Cangkang Telur Ayam sebagai Penambah Nutrisi Kalsium pada Tanaman Bayam (Amaranthus tricolor L.) dengan Budidaya Hidroponik. Skripsi. Institut Pertanian Bogor.

Juliani, V. (2017). Pengaruh Pemberian Ampas Kopi terhadap Pertumbuhan Tanaman Cabai Merah Keriting (Cupslcum annum var. Langun L.) dan Pengajarannya di SMA Negeri 5 Palembang. Skripsi. Universitas Muhammadiyah Palembang.

Kasongo, R. K., Verdoodt, A., Kanyankagote, P., Baert, G., \& Ranst, E. V. (2011). Coffee waste as an alternative fertilizer with soil improving properties for sandy soils in humid tropical environments. Journal of Soil Use and Management, 27(1), 94-102.

Manis, I., Supriadi., \& I. Said. (2017). Pemanfaatan limbah kulit pisang sebagai pupuk organik cair dan aplikasinya terhadap pertumbuhan tanaman kangkung darat (Ipomea reptans Poir). Jurnal Akademika Kimia, 6(4), 219-226.

Masayu. (2015). Pengaruh konsentrasi pupuk organik cair kulit pisang terhadap pertumbuhan dan hasil kedelai (Glycine max (L.) Merril). Jurnal Sekolah Tinggi Ilmu Pertanian Graha Karya Muara Bulian, 1(1), 1-7.

Mashfufah, N. H. (2014). Uji Potensi Pupuk Organik dari Bahan Cangkang Telur untuk Pertumbuhan Tanaman Seledri (Apium graveolens L.). Skripsi. Universitas Muhammadiyah Surakarta.

Munawar, A. (2011). Kesuburan Tanah dan Nutrisi Tanaman. IPB Press: Bogor.

Nur, T. A. R., Noor., \& Elma, M. (2016). Pembuatan pupuk organik cair dari sampah organik rumah tangga dengan penambahan bioaktivator EM4 (Effective Microorganisms). Jurnal Konversi, 5(2), 5-12.

Pappang, S. M. (2018). Pengaruh Lama Fermentasi Mikrobial Bioaktivator EM4 pada Pupuk Cair Ampas Kopi Torabika Toraja (Coffea arabica Toraja) terhadap Pembentukan Kandungan Nitrogen dan Fosfor Total. Skripsi. Universitas Sanata Dharma.

Patti, P. S., Kaya, E., \& Silahooy, C. (2013). Analisis status nitrogen tanah dalam kaitannya dengan serapan $\mathrm{N}$ oleh tanaman padi sawah di Desa Waimital, Kecamatan Kairatu, Kabupaten Seram bagian barat. Agrologia, 2(1), 51-58.

Rahmadina., \& Tambunan, E. P. S. (2017). Pemanfaatan limbah cangkang telur, kulit bawang dan daun kering melalui proses sains dan teknologi sebagai alternatif penghasil produk yang ramah lingkungan. Klorofil, 1(1), 48-55.

Salisbury, F. B., \& Ross, C.W. (1995). Fisiologi Tumbuhan Jilid 1. 4th Ed. ITB Press: Bandung.

Sitompul, S. M. (2015). Nutrisi Tanaman: Diagnosis Defisiensi Nutrisi Tanaman. Universitas Brawijaya Press: Malang.

Sriningsih, E. (2013). Pemanfaatan Kulit Buah Pisang (Musa paradisiaca L.) dengan Penambahan Daun Bambu (EMB) dan EM4 sebagai Pupuk Cair. Skripsi. Universitas Muhammadiyah Surakarta.

Sudradjat, R. (2007). Mengelola Sampah Kota. Penebar Swadaya: Jakarta.

Sugiyono. (2012). Statistika untuk Penelitian. Alfabeta: Bandung.

Nurjayanti, D., Zulfita, D., \& Raharjo, D. (2012). Pemanfaatan tepung cangkang telur sebagai substitusi kapur dan kompos keladi terhadap pertumbuhan dan hasil cabai merah pada tanah aluvial. Jurnal Sains Mahasiswa Pertanian, 1(1), 16-21.

Sutedjo, M. M. (2008). Pupuk dan Cara Pemupukan. PT Rineka Cipta: Jakarta.

Syam, Z. Z., Kasim, H. A., \& Nurdin, M. (2014). Pengaruh serbuk cangkang telur ayam terhadap tinggi tanaman Kamboja Jepang (Adenium obesum). e-Jipbiol, 3 (1), 9-15. 